\title{
HAIGHT, Roger. Jesus, símbolo de Deus. Trad. Jonas P. dos Santos. São Paulo: Paulinas, 2003. 576p.
}

Antonio Carlos Silva Ribeiro

A punição de teólogos sempre pareceu a protestantes uma agressão à inteligência. De uns tempos para cá, os gritos da comunidade teológica têm denunciado a sentença brandida para impor a solidão e o alarido de instâncias impessoais - como tambores, instrumentos de sopro e cantos usados para emudecer as crianças sacrificadas a Moloch, na Gehena - onde o pior era a punição não ter sentido. E foi a busca do sentido que animou a comunidade de fé, das periferias do poder, silenciosa e ágil, a defender as cristologias que partem dos seres humanos pobres e em meio aos conflitos existenciais e éticos, como as cristologias de Schillebeeckx, Sobrino, Martini e Haight.

A obra Jesus, símbolo de Deus é resultado de muitos anos de ensino teológico na Weston School of Theology, dirigida pelos jesuítas em Cambridge. Notificado, Haight não deixou de ensinar teologia, indo para o Union Theological Seminary, de Nova Iorque, sem missio canonica, mas na companhia de teólogos(as) como Niebuhr, Tillich, Sölle, Bonhoeffer, Williams, Cone, entre outros(as). Dividida em 16 capítulos, a obra tem quatro partes - questões de método, fontes bíblicas, a tradição clássica e cristologia construtiva. O autor não pretende "acomodar a mensagem evangélica à cultura humana, e sim permitir que a substância do evangelho assuma a forma de uma cultura local" (p. 11). Por essa razão não toma parte do debate da igreja romana, preferindo dialogar com "teólogos cristãos de diferentes denominações para, nas coordenadas do terceiro milênio, apresentar a fé cristã, de maneira inteligível, a pessoas instruídas, de dentro e de fora da Igreja" (p. 12), projetando o significado histórico e hermeneuticamente relevante para a atualidade.

Ele começa falando da pós-modernidade, da consciência do pluralismo e da responsabilidade diante da humanidade nestes tempos, concluindo que a teologia cristã é uma disciplina pluralista e que esse caráter alcança a sociedade, inclusive as igrejas. Mesmo que inspiração e inerrância ainda tivessem significado, a citação de um texto não 
estabelece um posicionamento teológico, possível apenas através da hermenêutica. Por esta leitura, a encarnação não se opõe ao humano, mas o completa e realiza, razão pela qual a cristologia pode ser transcendental, narrativa, existencial, liberacionista, feminista, inculturada, processual, a partir de uma compreensão apologética que avançou da inserção na cultura para a explicação da fé, e depois para a partilha da figura pública de Jesus de Nazaré, superando a visão proselitista e chegando à pluralista. Apoiado no tripé Rahner, Hick e Tillich, Haight desenvolve a noção de símbolo, partindo dos aspectos epistemológicos transcendentais e categoriais da religião para chegar ao relato teológico dramático, histórico e narrativo. Conforme o teólogo, seguindo de perto Tillich, a importância do símbolo provém do fato que a "religião é a substância da cultura; a cultura é a forma da religião" (p. 29).

Com essa chave hermenêutica, Haight descreve as formas como Jesus foi apropriado pela cristologia, a noção de Deus que o movia, o testemunho da ressurreição e seu significado, e o pluralismo já presente nas cristologias e soteriologias neotestamentárias. Mergulha na tradição clássica, discutindo o caráter histórico, a estrutura do símbolo; as soteriologias oriental, ocidental, reformada e tradicional; a cristologia em diálogo com a cultura desde os primórdios; e Niceia e Calcedônia. E, por fim, detém-se na cristologia que ele chama construtiva, por começar o diálogo com a modernidade, através de Schleiermacher e Barth, para discuti-la em tempos pós-modernos, rever o papel da Tradição, conectá-la com a soteriologia, entendê-la pela ótica das teologias da libertação, avançar para o debate com as religiões mundiais, admitindo a importância da maturidade para discutir a normatividade de Jesus, superar a relação de posse e abrir novos caminhos. Para ele, a nova cristologia vai surgir do diálogo da tradição com a pluralidade deste tempo, incluindo o Logos e o Espírito, reconceituando pericoreticamente a Trindade, a partir de baixo, para fazer jus ao Deus trinitário e corresponder à expectativa da modernidade.

Lidar com um tema de ponta implica novas perguntas, para as quais a teologia precisará buscar respostas, como é próprio de sua tarefa. Explicar a públicos cristãos tradicionais que Buda, Krishna e Maomé também podem ser símbolos válidos de Deus vai exigir muita tinta e o dobro de paciência para pressões, desacatos, punições - públicas e veladas - e, pelo menos, incompreensões. $\mathrm{O}$ (a) teólogo(a) não pode sequer sucumbir à 
vitimização, já que a situação não é privilégio da teologia, especialmente se a perspectiva for inovadora. Newton, Freud, Einstein, Reisenberg e Osvaldo Cruz enfrentaram os mesmos dilemas, mas sem risco de vida, já que nenhuma instituição moderna tem poder espiritual e temporal. A diferença talvez seja não terem sofrido perseguição de uma instituição mundial nem terem sido acusados de desrespeitar ou corromper o sagrado.

Ademais, mesmo com os desdobramentos presentes em Dinâmica da Teologia e $O$ futuro da cristologia, há aspectos e falhas que só serão corrigidos em obras posteriores. Essas são situações frentes às quais o autor pode parecer hesitante ou ambíguo, especialmente diante de afirmações clássicas como "Cristo é a palavra eterna de Deus", ou distinções singelas como indagar se o "Espírito Santo é pessoa real da Trindade", o que pode levar à heresia do triteísmo.

Essas formulações (formulae) não foram vistas como novos e inovadores caminhos para falar do mistério da fé à modernidade, mas como ultrapassagem dos limites aceitáveis para a doutrina cristã tradicional, concepção que exigiu um processo, a partir do qual o autor recebeu uma Notificatio em dezembro de 2004, sendo proibido de ensinar em instituição católica. Mesmo tendo atendido à exigência, já que o Union sequer pertence a instituição eclesial, foi exigido ainda que ele não ensine em lugar algum. Todavia, como tem mostrado a prática católica recente, a opção por continuar seu mister é do próprio teólogo, que pode ensinar e publicar onde quiser. Com protestantes, essa atitude remonta ao século XVI, quando Lutero, excomungado pelo Papa Leão X, da Igreja Católica Romana, e banido pelo Imperador Carlos V do Sacro Império Romano Germânico, continuou dando aulas na Universidade de Wittenberg - com a proteção do Estado, gesto que Hans Küng repetiu em 1996 na Universidade de Tübingen.

As perguntas teológicas que surgiram têm origem e intenções distintas. Algumas se aferram a formulações dogmáticas e têm a intenção de acusar e punir. É o caso de questões como estas: Jesus como ser humano "simbolizou" ou "mediou" a presença salvadora de Deus?; Jesus suportou a punição pelos nossos pecados, ou morrer pela justiça de Deus ainda tem sentido hoje?; Jesus pode ser normativo para os cristãos, mas não constitutivo para outras religiões?

Outras são as levantadas pela comunidade teológica. As teorias de Haight geraram um animado debate dentro da teologia católica, com aplausos e indagações, e, em certo 
sentido, a notificação de 2005 deu eco às críticas dos teólogos. Num debate organizado em 1999 pela Sociedade Teológica Católica dos Estados Unidos, William Loewe, da Catholic University of America, sugeriu que, ao tratar a segunda e a terceira pessoas da Trindade como símbolos, Haight acaba propondo um Deus Unitário e um Jesus meramente humano. O teólogo John Cavadini, professor de Notre Dame e consultor do Comitê de Doutrina dos bispos norte-americanos, escreveu, em Commonweal, que "há uma diferença entre tornar a fé cristã inteligível à cultura e reduzir suas afirmações teológicas centrais em uma declaração que até um ateu pode afirmar". Gerald O'Collins afirmou ao NCR: "Eu não daria a minha vida pelo Jesus de Roger Haight. É o triunfo da relevância sobre a ortodoxia". Paul Lakeland, da Fairfield University, considerou que ele parece certo "ao abraçar a intuição moral moderna que nos diz que estamos fora de nossa profundidade e além de nossos direitos quando tentamos confinar o Espírito à história cristã".

Se o Vaticano tem razão, teologias pluralistas como a de Haight comprometem verdades centrais da fé: se o cristianismo não pode confessar Jesus como o único salvador do mundo, perdeu sua raison d'être. E correm o risco de solapar as energias missionárias da igreja e abrir caminho para a perda da identidade cristã. Já para Haight, a questão central não é apenas a ambição cristã de aproximar-se de outras religiões para 'colonizá-las', mas a plausibilidade da pregação do evangelho num mundo pós-moderno. Mais, seu discurso é o único que serve à ação missionária das igrejas, especialmente no Ocidente, onde o pluralismo é o preço para a participação no diálogo, que tem sido chamado de Teologia Pública. Ele pode obedecer integralmente às exigências do Vaticano, sucumbindo à punição, mas já está na lista dos teólogos mais publicados. 